\title{
Home Bias and Corporate Environmental Social Responsibility
}

\author{
Xing Rong ${ }^{1}\left(\mathbb{D}\right.$, Bingjie Song ${ }^{2}{ }^{\mathbb{D}}$, Tingting Zhang ${ }^{1}$ and Kai Liu ${ }^{3,4, *} \mathbb{C}$ \\ 1 School of Insurance, Southwestern University of Finance and Economics, Chengdu 611130, China; \\ rx865@126.com (X.R.); zhangtt@swufe.edu.cn (T.Z.) \\ 2 School of Accounting, Southwestern University of Finance and Economics, Chengdu 611130, China; \\ songbingjie@smail.swufe.edu.cn \\ 3 School of Mathematical and Computational Sciences, University of Prince Edward Island, \\ Charlottetown, PE C1A 4P3, Canada \\ 4 Big Data Research Lab, University of Waterloo, Waterloo, ON N2L 3G1, Canada \\ * Correspondence: kailiu@upei.ca
}

check for

updates

Citation: Rong, X.; Song, B.; Zhang, T.; Liu, K. Home Bias and Corporate Environmental Social Responsibility. Sustainability 2021, 13, 5860. https:// doi.org/10.3390/su13115860

Academic Editors: Josep Maria Raya and Marian Buil

Received: 16 April 2021

Accepted: 20 May 2021

Published: 23 May 2021

Publisher's Note: MDPI stays neutral with regard to jurisdictional claims in published maps and institutional affiliations.

Copyright: (c) 2021 by the authors. Licensee MDPI, Basel, Switzerland. This article is an open access article distributed under the terms and conditions of the Creative Commons Attribution (CC BY) license (https:/ / creativecommons.org/licenses/by/ $4.0 /)$.

\begin{abstract}
This paper analyzes the impact of executives' hometown identification on corporate environmental social responsibility (CESR) using a sample of Chinese A-share-listed companies from 2007 to 2018. It finds that: the CESR scores of companies are higher when executives work in their hometowns, indicating that executives' hometown identification significantly improves the fulfillment of CESR; mechanism tests show that the above relationship is more significant in regions with superior environmental quality, indicating that executives take CESR more seriously in their hometowns more due to social pressure; further tests found that executive characteristics, such as executive type and age, have a regulating effect on this relationship. In addition, the nature of property rights of listed companies also affects executives' hometown identification. Executives of state-owned enterprises have a stronger hometown identification, which enhances the fulfillment of CESR to a higher extent. In the context of the micro level of the enterprise, this paper provides positive evidence that an informal system, named as "hometown identity", can enhance the performance of CESR and the pressure effect implicitly behind the social network, which enriches and expands the research related to CESR fulfillment.
\end{abstract}

Keywords: hometown identity; environmental social responsibility; informal system

\section{Introduction}

As an important part of China's sustainable economic and social development, the establishment of ecological civilization and protection of an ecological environment are receiving increasing attention from the central government and various regional authorities. With the increasing pressure on the establishment of ecological civilization, the government and society have put forward higher requirements for the construction and improvement of the corporate responsibility framework for the environment [1], and a series of formal environmental policies, systems and regulations have been introduced to promote and improve the fulfillment of corporate environmental responsibility. The analysis of CESR reports in 2020 showed that the percentage of reports named "environment, social and governance reports" has increased from $2.02 \%$ to $22.66 \%$, and the degree of disclosure on environmental aspects such as pollution reduction and emission reduction has also increased significantly compared to the base period [2]. However, the domestic ecological environment is still at the brink of danger, and the structural, root and trend pressure of ecological environmental protection is kept at a high level [3]. The performance of corporations on Eco-environmental protection will remain a focus of the government and of society.

Academics have mostly focused on the influence of formal institutions such as laws and regulations [4], environmental regulation [5] and legal environment [6] on corporate environmental governance, while a small number of studies have looked at the influence 
of media legitimacy [7], traditional culture [8] and other informal institutions to explore the positive aspects of corporate social responsibility on the Eco-environment. As the soil of formal institutions, various informal institutions such as culture, customs and practices accumulated in regions over a long historical process often exert the power to drive society forward together with formal institutions [9]. This article also cuts into the informal system and analyzes its impact on the performance of CESR from the perspective of choosing the hometown preference of executives. Early literature about the phenomenon of home bias in economic activities focused on whether the transaction cost of non-home investment increased $[10,11]$ and whether information was symmetrical [12-15], introduced the identity into the neoclassical analysis framework, and proposes the theory of identity economics, which argues that individual utility maximization may be achieved in the form of gains to the identity group, in addition to the individual's own behavior. Especially in a culture where collectivism is thriving, collective interests are given an important position. When various strata within the organization pursue their own interests, individuals often do not try their best to seek self-interest in order to maintain consistent external collective interests, such as harmony, fairness, etc. China is a collectivist country with a strong collectivism in its traditional culture and values $[16,17]$. This provides a good scenario for us to study the impact of executives' hometown identity on corporate behavior. On this basis, we chose Chinese listed companies as the research objects to explore the impact of senior executives' hometown preference on companies' performance of their environmental and social responsibilities. China, influenced by thousands of years of Confucianism and traditional culture, has a natural "hometown complex" as the emotional basis for local identity, especially hometown identity. Since ancient times, the hometown has held a special place in people's hearts, and this sentiment can be felt in almost every era. Typical examples include the popular poem "Raising my head to look at the bright moon and thinking of my hometown" by Tang Dynasty poet Bai Li, and the famous poem "Nostalgia" by modern poet Guangzhong $\mathrm{Yu}$, which reflect people's attachment and sense of identity to their hometown, as well as the existence of important identity characteristics in their hometown.

This hometown identity has been widely discussed in the allocation of resources by officials to their hometowns. As a form of rent-seeking or corruption [18], officials prefer to tilt resources toward their hometowns with more transfer payments [19] and congressional appropriations [20], which results in higher economic growth in their hometowns [18]. This also exists in China and is highlighted in regional favoritism towards home regions [21-26]. This paper applies this analysis of official-level regional favoritism to that of firm executives' preferences for their hometowns, which may lead executives to exhibit more friendly attitudes toward their hometown environment due to their unique emotions toward their hometowns, thus influencing their social responsibility on the Eco-environment.

Using a sample of Chinese A-share listed companies from 2007 to 2018, this paper analyzes the impact of executives' hometown identity on corporate environmental social responsibility. It is found that when executives work in their hometown, the CESR scores of enterprises are higher, indicating that executives' hometown identity significantly enhances the fulfillment of corporate social responsibility on the Eco-environment; however, mechanism tests show that the above relationship is more significant only in regions with superior environmental quality, indicating that more executives perform corporate social responsibility (CSR) in their hometowns because of the pressure of social networks; further tests find that executive characteristics (executive type, age) have a moderating effect on the above relationship. In addition, the nature of the property rights of listed companies will also affect the environmental CSR performance of senior executives. We found that in state-owned enterprises, hometowns prefer to enhance the performance of CESR.

Compared with the existing literature, the contribution of this article is summarized as follows.

First, it expands the cognition of identity theory. The identity theory proposed by [12] is based on the sense of individual self-identity. This paper selects China with strong local concepts for testing and finds that the hometown preference of executives in fulfilling 
environmental and social responsibilities is more based on their pressure in social networks. It not only expands the literature on the impact of home bias on enterprises but also expands our understanding of identity theory.

Second, it expands the relevant research on the motivation of CSR fulfillment. The existing literature on CSR uses economic incentive motivation [27], legitimacy motivation [28] and moralistic motivation [29]. This article expands the related research on moralist motivation. From the individual level of senior executives, this paper discusses the factors affecting the performance of environmental and social responsibilities in their hometown.

\section{Theoretical Analysis and Research Hypothesis}

\subsection{Home Bias and CESR Fulfillment}

In the Chinese situation, hometown is an important dimension of identity. References [12-14] introduce identity into the analytical framework of neoclassical economics and proposed Identity Economics, which argues that individual utility depends on three factors, one's own behavior, the behavior of others in the group, and identity. This means that maximizing the individual's utility depends not only on the individual's own behavior but also on the influence of others in the group on him or her and his or her identity in the group $[9,12]$. According to this theory, identity is a social norm that can influence human behavior and decision making.

The Chinese have a widespread concept of homeland, and identification with one's hometown may give one a certain degree of attachment to the question of "where I come from". Reference [30] also pointed out that the basic ethical characteristic of Chinese culture is relational orientation, and that place of origin by itself constitutes an important dimension of social relations. In China, people's emotional attachment to their hometowns has existed throughout history, such as in the ancient poems, "To be alone in a foreign land is to be a stranger, and to think of one's relatives whenever the festive season comes" and "To raise one's head to look at the bright moon, and to bow one's head to think of one's hometown"; the same applies to contemporary poetry, such as Guangzhong Yu's "Nostalgia". The difficulty in getting a ticket during the Spring Festival and the rush to go home to pay respects to ancestors during the Qingming Festival are also concrete manifestations of hometown identity in today's Chinese society [31], and there is also a large number of "hometown associations" in various places to better connect hometown networks. Executives have a natural affection for their hometowns and are naturally motivated to give back to their hometowns, and to a certain extent, they are also bound by moral opinion. From the perspective of identity economics, the "hometown identity" of executives makes them subject to the corresponding social norms, which affects their behavior and decisions.

When a company's registered place of operation happens to coincide with the executive's hometown, the company's environmental pollution behavior will inevitably have an impact on the environmental quality of the executive's hometown. Therefore, can this hometown identity of corporate executives influence the environment-related behavior of the company? This paper attempts to explore this question. Combining the theoretical foundations of identity economics, we analyze how executives' hometown identity affects their environmental protection decisions from both internal and external perspectives and argue that executives' hometown identity improves the level of fulfillment of the corporate social responsibility on Eco-environment.

Internally, executives' hometown identity deeply influences executives' attitudes and behaviors toward their hometown environment. First, executives with hometown identity have more respect and care for their hometown environment. Qing Ai's poem “Why are my eyes often full of tears, because I love this land so much" fully expresses people's love and attachment to their hometown. Executives show a more friendly attitude toward their hometown environment, respecting and caring for their hometown environment so as to restrain the pollution behaviors of enterprises to some extent. At the same time, executives' love for their hometown may reduce executives' self-interest at the expense of the environ- 
ment, such that executives are less likely to engage in profit-seeking behavior at the expense of destroying the environment and may even devote more resources to environmental protection investment and protect the hometown environment [31]. Second, executives' hometown identity will motivate executives to pay more attention to the demands of home environment-related stakeholders for environmental protection. Environmental pollution, on the one hand, poses a great danger to the physical and mental health of people from the hometown and, on the other hand, it is not conducive to the sustainable development of hometown and people from the hometown have increasing demands for environmental quality. Studies such as [32-36] illustrate from several perspectives that China is a relational society, and the conflicting or congruent interests of each entities in a multiple-lateral relationship can significantly affect each other's behavior. Local executives have strong social ties with their hometown people, and the families, clans, and friends of local executives are likely to be more clustered in their hometowns. Not only does hometown identity have a unique aesthetic and symbolic meaning in people's minds, but hometown is also a setting that allows people to consciously or subconsciously integrate themselves into their hometown environment [37]. From this perspective, executives' hometown identity may lead executives to pay more attention to the feelings of stakeholders around the company and meet their environmental demands. An example of this is making more environmental investments to improve the efficiency of energy consumption and reduce emissions of waste gas and wastewater, etc.; thus, environmental business operations conflict with environment-related stakeholders.

Externally, executives' hometown identities create greater moral opinion pressure and reputational pressure on them. People from one's hometown have higher expectations of local executives in terms of environmental protection than people outside the hometown, and these expectations grow stronger as environmental awareness grows. They believe that as "their own people", local executives should be grateful to their hometown where they were "raised" and have the responsibility and ability to protect their hometown environment, and that failure to protect or destroy it is deemed as an act of forgetfulness. In addition, the reputation of "ungratefulness" can cause executives to lose the hometown network capital formed by their hometown identity. The strong hometown ties form a hometown network with stronger emotional dependence, binding force and cohesiveness [38], which provide important resources and social relationships with each other, but executives who destroy the hometown environment will greatly hurt the feelings of their fellow countrymen and thus lose the whole hometown network [39]. Therefore, emotional ties and dependencies may influence executives to hold their companies' behavior to higher environmental standards, to comply more actively with environmental rules, to reduce their companies' polluting behavior and to protect their hometown environment.

Taken together, the hometown identity of local executives helps executives focus on environmental protection factors in their production and management decisions, which is conducive to the fulfillment of corporate social responsibility on the Eco-environment. Based on the above analysis, we propose the following hypotheses:

Hypothesis 1 (H1a). When the executives' place of origin is the same as the company's registered place, the company can better fulfill its environmental social responsibility due to the executives' hometown identity relative to other companies.

\subsection{Hometown Social Network and Corporate Environmental Social Responsibility (CSR) Avoidance}

We put forward the theoretical relationship between Home Bias and CSR performance described above based on the identity theory. However, there is another logical line in the impact of corporate executives' role of "hometowner" on the environmental CSR. Since the fulfillment of environmental social responsibility will affect all aspects of the production and operation of enterprises [40] and increase the cost of enterprises, polluting enterprises in particular are not proactive in environmental CSR. Most of their CSR performance in the environmental aspect is a passive response to the government's environmental manage- 
ment policies and economic incentive measures [41]. When the hometown of executives is the same as the place where the company is registered, in addition to the personal characteristics of identity, the executives also have a denser social network and resources in their hometowns, and they have the advantages of information transmission and resource acquisition $[42,43]$. All of these help senior executives to establish contact with the government and environmental control departments, thereby avoiding environmental control risks and reducing corporate costs by minimizing performance in terms of environmental and social responsibilities. Based on this factor, we propose a competitive hypothesis $(\mathrm{H} 1 \mathrm{~b})$ against H1a:

Hypothesis $\mathbf{1} \mathbf{( H 1 b ) . ~ W h e n ~ t h e ~ h o m e t o w n ~ o f ~ t h e ~ e x e c u t i v e s ~ i s ~ t h e ~ s a m e ~ a s ~ t h e ~ p l a c e ~ w h e r e ~}$ the company is registered, compared with other companies, the executives can use their social network advantages to circumvent environmental regulations and hence the company will show less environmental and social responsibility.

\section{Experimental Design}

\subsection{Sample Selection and Source of Data}

The sample period of this article started in 2007 because China's new accounting standards were implemented in 2007. To make the statistics of accounting data more comparable, this article uses the 2007-2018 Shanghai and Shenzhen A-share listed companies as the primary sample. Based on the preliminary sample, the resumes of executives (chairman and CEO) disclosed in Wind Financial Database at (http:/ / www.wind.com.cn, accessed on 8 January 2020) and CSMAR Database at (http:/ / www.gtadata.com, accessed on 8 January 2020) and information of origin and place of birth were first sorted out and then processed to fill out the missing data. The information related to the chairman and CEO of listed companies, such as gender, age, education, place of origin and birthplace was then manually searched and sorted through Baidu, Sogou and Google. In terms of environmental social responsibility, the CSMAR database collated information on whether companies disclosed environmental and sustainable development and the corresponding project values based on their annual reports, and the CNRDS database (https: / /www.cnrds.com, accessed on 8 January 2020) compiled detailed project data on whether companies conducted green office and environmental certification. After the above data processing, this paper finally obtained 5629 sample observations. To control the influence of outliers, this paper used WINSORIZE on the continuous variables by upper and lower $1 \%$.

\subsection{Variable Definitions}

\subsubsection{Dependent Variables}

Social responsibility on Eco-environment (EnvCsr) is the dependent variable in this paper. This paper draws on the study of [44], in which the CSR on Eco-environment items are subdivided, and the social responsibility on Eco-environment (EnvCsr) was obtained by summing the environmental advantage scores and subtracting the environmental concern scores. In addition, internal (personal emotion) and external (external pressure) mechanisms mentioned in the theoretical analysis generally coexist in the process of influencing CESR behavior, and which of the two has a more important need to be analyzed by comparing the CESR behavior sub-indicators. Therefore, this paper also distinguishes between positive environmental behaviors (EnvCsr_good) and negative environmental behaviors (EnvCsr_bad) to clarify the influence mechanism of hometown identity on CESR behaviors.

\subsubsection{Explanatory Variables}

Executive hometown identity (Nati) is the explanatory variable of this paper. Hometown identity is an informal institution; moreover, it is a social norm. Reference [30] pointed out that the basic ethical characteristic of Chinese culture is that it is relationship-based, and hometown origin constitutes an important dimension in social relationships. People gener- 
ally still have a natural attachment to their hometowns, which may lead to the motivation of protecting them. In this paper, the subjects of empirical analysis are listed companies, and according to the principle of importance, we chose the chairman and the general manager as the research subjects to measure their hometowns by their places of origin. As mentioned earlier, for several reasons, this paper did not use questionnaires and interviews to measure executives' (chairman or CEO) hometown identification, but rather measured it by comparing the hometown of company executives and the company's registered region. This paper assumes that each executive has an identity with their respective hometown, but not every company's executives serve in their own hometown, which leads to differences in executives' sentiments toward their company's registered place of business. If the place of incorporation of a listed company was the hometown of the executive (chairman or CEO), the executive is considered to have hometown identification with that region. Specifically, in this paper, drawing on [45]'s study on executives' political affiliation, we set executives' hometown identification as a dummy variable Nati: when the place of origin of a listed company's executive (chairman or CEO) was in the same province as the company's registered place, it was assigned a value of 1 ; otherwise it was 0 . When searching executives' CVs by hand, we found that most of the executives' hometown information could only be retrieved to the administrative province, whereas only a few of them were specific to "province + city". Therefore, in the main test, we measured the hometown identification of listed executives by using province as the benchmark to indicate their place of origin and compare it with the company's registered province. In the robustness test, the hometown identification was mixed with "province + city": if the city of origin could be searched, the city of origin was compared with the city of incorporation, and if not, only the province was compared.

\subsubsection{Control Variables}

Drawing on the study by [31], the variables affecting CESR are controlled in four dimensions: firm fundamentals, corporate governance, macroeconomy variables and executive characteristics. Firm fundamentals include firm size (Size), financial leverage (Lev), growth capacity (Grow), profitability (Roa) and cash flow from operating activities (Fcf); corporate governance variables include nature of ownership (Soe), majority shareholder ownership (Top1) and shareholder structure (Stru). At the same time, because the company may set its registration place to financially developed regions such as Shenzhen and Shanghai to facilitate the acquisition of financial resources when registering, but there are differences between the actual business place and the registration place. In this case, we added the parent company's self-operating ratio (PCSQ). This variable measures the proportion of operating income in the parent company's income statement to the operating income in the consolidated income statement. Macroeconomy variables includes regional gross domestic product per capita (PerGdp), regional legal environment (Law) and regional environmental quality (PM25); executive characteristics include gender (Gender), age (Age) and education (Degree). In addition, industry (Ind) and year (Year) dummy variables are added to control for industry and time effects. Detailed definitions of all variables are shown in Table 1. 
Table 1. Definition and description of main variables.

\begin{tabular}{|c|c|c|c|}
\hline Nature of Variables & Variable Name & Variable Symbols & Variable Definition \\
\hline \multirow{3}{*}{ Dependent variables } & $\begin{array}{l}\text { Environmental Social } \\
\text { Responsibility }\end{array}$ & EnvCsr & $\begin{array}{c}\text { Total positive environmental behavior } \\
\text { score-Total negative environmental } \\
\text { behavior score }\end{array}$ \\
\hline & $\begin{array}{l}\text { Positive Environmental } \\
\text { Behavior }\end{array}$ & EnvCsr_good & $\begin{array}{l}\text { Whether the enterprise produces } \\
\text { environmentally beneficial products, } \\
\text { minimizes three wastes, has circular } \\
\text { economy, saves energy, has green office, } \\
\text { has environmental certification; } 1 \text { if yes, } \\
0 \text { otherwise; then sum up }\end{array}$ \\
\hline & $\begin{array}{l}\text { Negative Environmental } \\
\text { Behavior }\end{array}$ & EnvCsr_bad & $\begin{array}{l}\text { Whether the enterprise has recent } \\
\text { environmental penalties and pollutant } \\
\text { emissions; } 1 \text { if yes, } 0 \text { otherwise; then } \\
\text { sum up }\end{array}$ \\
\hline Explanatory variables & $\begin{array}{l}\text { Executives' hometown } \\
\text { identity }\end{array}$ & Nati & $\begin{array}{l}\text { Indicator of whether the company is } \\
\text { registered in the same province as the } \\
\text { executive (chairman or CEO) }\end{array}$ \\
\hline \multirow{15}{*}{ Control variables } & Company Size & Size & Natural logarithm of total assets \\
\hline & Financial leverage & Lev & $\begin{array}{l}\text { Ratio of total company liabilities to } \\
\text { total assets }\end{array}$ \\
\hline & Growth Capacity & Grow & Operating income growth rate \\
\hline & Profitability & Roa & Return on Total Assets \\
\hline & Operation cash flow & Fcf & $\begin{array}{l}\text { Ratio of net cash flow from operating } \\
\text { activities to total assets }\end{array}$ \\
\hline & Nature of ownership & Soe & $\begin{array}{l}\text { Indicator of whether the company is a } \\
\text { state-owned entity }\end{array}$ \\
\hline & Major shareholder holdings & Top1 & $\begin{array}{c}\text { Percentage of shares held by the largest } \\
\text { shareholder }\end{array}$ \\
\hline & Equity Structure & Stru & $\begin{array}{l}\text { Concentration of shareholdings of the } \\
\text { top five shareholders }\end{array}$ \\
\hline & $\begin{array}{l}\text { Parent company's } \\
\text { self-operating ratio }\end{array}$ & PCSQ & $\begin{array}{l}\text { Measured by the proportion of } \\
\text { operating income in the parent } \\
\text { company's income statement to the } \\
\text { operating income in the consolidated } \\
\text { income statement }\end{array}$ \\
\hline & GDP per capita & PerGDP & $\begin{array}{l}\text { Gross regional GDP/Total } \\
\text { regional population }\end{array}$ \\
\hline & Local Legal Environment & Law & $\begin{array}{c}\text { The environmental index of the legal } \\
\text { system in each region compiled by } \\
\text { Fan et al. (2016) }\end{array}$ \\
\hline & Local environmental quality & PM25 & $\begin{array}{l}\text { Annual average PM2.5 } \\
\text { concentration }\left(\mu \mathrm{g} / \mathrm{m}^{3}\right)\end{array}$ \\
\hline & Age & Age & Average age of the Chairman and CEO \\
\hline & Gender & Gender & $\begin{array}{l}\text { Indicator of whether at least one of the } \\
\text { chairman or CEO is a woman }\end{array}$ \\
\hline & Education & Degree & $\begin{array}{c}\text { Junior college and below }=1, \\
\text { college }=2, \text { bachelor }=3, \text { master }=4, \\
\text { doctor }=5 \text {; if the chairman and CEO } \\
\text { have different education, the higher } \\
\text { education is taken }\end{array}$ \\
\hline
\end{tabular}




\subsection{Model Construction}

In order to examine the influence of executives' hometown identification on corporate social responsibility on Eco-environment, the following models are constructed to test Hypothesis $\mathrm{H} 1$ and Hypothesis H2, respectively:

$$
\text { EnvCsr }=\beta_{0}+\beta_{1} \text { Nati }+\beta_{2} \text { Control }+ \text { Year }+ \text { Ind }+\varepsilon
$$

In the above equation, the dependent variable is social responsibility on Eco-environment (EnvCsr), which includes all dimensions in this aspect. The explanatory variable is executive hometown identification (Nati) and Control is an ensemble of a set of control variables. This paper focuses on the regression coefficient $\beta_{1}$. If $\beta_{1}$ is significantly greater than 0 , it verifies the inference of hypothesis $\mathrm{H} 1$ that the fulfillment level of CSR on Eco-environment is higher when the executives' place of origin is the same as the place of corporate registration compared to other firms. To test hypothesis 2 , we divide the sample into two groups based on the median annual average concentration of PM2.5 in the province where the enterprise is located, namely good regional environmental quality and poor regional environmental quality. If there is a significant negative relationship between executives' home country identification and both positive and negative environmental behaviors in the sample with good regional environmental quality, it means that "supply" is more important than "demand"; i.e., executives' moral sense of the environment prevails.

\section{Regression Results and Numerical Analysis}

\subsection{Descriptive Statistics}

Table 2 shows the results of descriptive statistics for the main variables in the full sample. Among them, the mean value of corporate social responsibility on Eco-environment (EnvCsr) is 2.833, with a standard deviation of 1.646, a minimum value of -1 and a maximum value of 8 . The range of EnvCsr is large, indicating that there are large differences in the fulfillment level of CSR on Eco-environment among different companies. The mean value of executives' hometown identification (Nati) is 0.394 , indicating that about two-fifths of the companies whose executives' hometown is in the same province as the company's registered office, which means that the phenomenon of executives working in their hometown is still relatively common among Chinese listed companies. In addition, the mean and median of the fundamental control variables, such as size, leverage, and growth, are consistent with most of the relevant studies. The mean values of Age, Gender and Degree are 51.420, 0.081 and 3.885, respectively, indicating that the average age of executives in the sample is about 51 years old, and most of them are male with an average level of education of bachelor's degree.

\subsection{Analysis of Regression Results}

Table 3 examines the regression results of the effect of executive hometown identification on corporate social responsibility on Eco-Environment. Column (1) of Table 3 reports the regression results of the impact of executive hometown identification alone on CESR behavior, and it can be observed that the estimated coefficient of executive hometown identification (Nati) is 0.128 and is significant at the 1\% level; in column (2), firm-level indicators such as firm size Size and financial leverage Lev are added, at which point the coefficient of Nati is 0.113 and is still significant at $1 \%$. In column (3), macro-level indicators such as PerGDP, Law and PM25 are added to the control variables, and the coefficient of Nati is still significant at the $1 \%$ level. In column (4), we further control for the effects of executives' personal characteristics, such as Age, Gender and Degree, and the estimated coefficient of Nati remains significantly positive at the $1 \%$ level. 
Table 2. Descriptive Statistics of the Main Variables.

\begin{tabular}{ccccccccc}
\hline Variable & $\mathbf{N}$ & Mean & Sd & Min & p25 & p50 & p75 & Max \\
\hline EnvCsr & 5630 & 2.839 & 1.645 & -1 & 2 & 3 & 4 & 8.000 \\
Nati & 5630 & 0.395 & 0.489 & 0 & 0 & 0 & 1 & 1.000 \\
Size & 5630 & 23.04 & 1.451 & 19.02 & 21.99 & 22.90 & 23.94 & 26.760 \\
Lev & 5630 & 0.493 & 0.198 & 0.057 & 0.344 & 0.506 & 0.646 & 1.033 \\
Grow & 5630 & 0.169 & 0.399 & -0.661 & -0.00400 & 0.104 & 0.263 & 3.520 \\
Roa & 5630 & 0.044 & 0.052 & -0.285 & 0.017 & 0.037 & 0.066 & 0.206 \\
Fcf & 5630 & 0.052 & 0.068 & -0.196 & 0.013 & 0.051 & 0.091 & 0.256 \\
Top1 & 5630 & 0.373 & 0.160 & 0.0880 & 0.240 & 0.362 & 0.496 & 1.000 \\
Stru & 5630 & 0.545 & 0.170 & 0.192 & 0.420 & 0.544 & 0.665 & 0.748 \\
PerGDP & 5630 & 6.406 & 2.916 & 1.332 & 4.003 & 6.197 & 8.298 & 0.894 \\
Law & 5630 & 5.380 & 2.751 & -1.130 & 3.410 & 5.250 & 7.490 & 12.890 \\
PM25 & 5630 & 37.91 & 15.71 & 6.380 & 25.47 & 35.60 & 49.60 & 10.000 \\
Age & 5630 & 51.41 & 4.859 & 38.50 & 48 & 51.50 & 54.50 & 71.410 \\
Gender & 5630 & 0.082 & 0.274 & 0 & 0 & 0 & 0 & 79.000 \\
Degree & 5630 & 3.891 & 0.758 & 1 & 4 & 4 & 4 & 1.000 \\
PCSQ & 5630 & 0.469 & 0.347 & 0 & 0.133 & 0.458 & 0.783 & 5.000 \\
\hline
\end{tabular}

Among the control variables, company size (Size), profitability (Roa), shareholding structure (Stru), regional legal environment (Law) and age (Age) are significantly and positively related to corporate social responsibilities on Eco-environment (EnvCsr). On the other hand, growth capacity (Grow), majority shareholder ownership (Top1) and gross per capita product (PerGDP) are significantly and negatively related to EnvCsr. Here, the company's growth is negatively related to environmental CSR. We speculate that it is because the company pays more attention to more profitable project investment during the growth period, thereby reducing investment in environmental projects and avoiding cost increases. Similarly, PerGDP and environmental CSR are also negatively correlated, indicating that if the regional economic development becomes better, the corresponding investment in environmental projects will be proposed, which leads to a negative correlation between PerGDP and environmental CSR. The estimated coefficients of legal environment (LAW) are all significantly positive, indicating that formal institutions such as environmental regulation have a propulsive effect on firms to perform environmental social responsibility and the findings are consistent with those of $[46,47]$.

In summary, it can be seen that executive hometown identification is positively related to CESR performance after controlling for firm characteristics, corporate governance, macro-level and executive characteristics, indicating that the informal institution of hometown identification contributes to the environmental performance of firms. The regression results in Table 3 support the research hypothesis H1a of this paper. 
Table 3. Hometown Identity of Executives and CSR on Eco-environment.

\begin{tabular}{|c|c|c|c|c|}
\hline & (1) & (2) & (3) & (4) \\
\hline & EnvCsr & EnvCsr & EnvCsr & EnvCsr \\
\hline Nati & $\begin{array}{c}0.128^{* * *} \\
(2.86)\end{array}$ & $\begin{array}{c}0.113^{* * *} \\
(2.65)\end{array}$ & $\begin{array}{c}0.156^{* * *} \\
(3.61)\end{array}$ & $\begin{array}{c}0.142^{* * *} \\
(3.27)\end{array}$ \\
\hline Size & & $\begin{array}{c}0.390 * * * \\
(19.55)\end{array}$ & $\begin{array}{c}0.367^{* * * *} \\
(18.31)\end{array}$ & $\begin{array}{c}0.364^{* * *} \\
(17.56)\end{array}$ \\
\hline Lev & & $\begin{array}{l}-0.079 \\
(-0.55)\end{array}$ & $\begin{array}{l}0.012 \\
(0.08)\end{array}$ & $\begin{array}{l}0.045 \\
(0.31)\end{array}$ \\
\hline Grow & & $\begin{array}{c}-0.165^{* * *} \\
(-3.09)\end{array}$ & $\begin{array}{c}-0.155^{* * *} \\
(-2.88)\end{array}$ & $\begin{array}{c}-0.130 \text { ** } \\
(-2.41)\end{array}$ \\
\hline Roa & & $\begin{array}{c}1.319 * * * \\
(2.77)\end{array}$ & $\begin{array}{c}1.210 * * \\
(2.54)\end{array}$ & $\begin{array}{c}1.147^{* *} \\
(2.42)\end{array}$ \\
\hline Fcf & & $\begin{array}{l}0.457 \\
(1.35)\end{array}$ & $\begin{array}{l}0.525 \\
(1.56)\end{array}$ & $\begin{array}{l}0.457 \\
(1.36)\end{array}$ \\
\hline Soe & & $\begin{array}{l}0.004 \\
(0.08)\end{array}$ & $\begin{array}{l}0.031 \\
(0.64)\end{array}$ & $\begin{array}{l}0.017 \\
(0.35)\end{array}$ \\
\hline Top1 & & $\begin{array}{c}-0.459^{* *} \\
(-2.33)\end{array}$ & $\begin{array}{c}-0.459^{* *} \\
(-2.35)\end{array}$ & $\begin{array}{c}-0.498^{* *} \\
(-2.55)\end{array}$ \\
\hline Stru & & $\begin{array}{c}0.582 * * * \\
(3.12)\end{array}$ & $\begin{array}{c}0.569 * * * \\
(3.07)\end{array}$ & $\begin{array}{c}0.570^{* * *} \\
(3.06)\end{array}$ \\
\hline PerGDP & & & $\begin{array}{c}-0.051^{* * *} \\
(-3.31)\end{array}$ & $\begin{array}{c}-0.053^{* * *} \\
(-3.40)\end{array}$ \\
\hline Law & & & $\begin{array}{c}0.112^{* * *} \\
(8.17)\end{array}$ & $\begin{array}{c}0.114^{* * *} \\
(8.33)\end{array}$ \\
\hline PM25 & & & $\begin{array}{l}-0.002 \\
(-1.29)\end{array}$ & $\begin{array}{l}-0.002 \\
(-1.61)\end{array}$ \\
\hline Age & & & & $\begin{array}{c}0.017 * * * \\
(3.77)\end{array}$ \\
\hline Gender & & & & $\begin{array}{l}-0.042 \\
(-0.55)\end{array}$ \\
\hline Degree & & & & $\begin{array}{l}-0.020 \\
(-0.76)\end{array}$ \\
\hline PCSQ & & & & $\begin{array}{c}0.111^{*} \\
(1.69)\end{array}$ \\
\hline Constant & $\begin{array}{c}1.680^{* * *} \\
(5.31)\end{array}$ & $\begin{array}{c}-6.582 \text { *** } \\
(-13.75)\end{array}$ & $\begin{array}{c}-6.549 * * * \\
(-13.73)\end{array}$ & $\begin{array}{c}-7.243^{* * *} \\
(-13.96)\end{array}$ \\
\hline $\mathrm{N}$ & 5630 & 5630 & 5630 & 5630 \\
\hline $\mathrm{R}^{2}$ & 0.056 & 0.156 & 0.169 & 0.172 \\
\hline
\end{tabular}

Note that the values inside the bracket are $t$-values based on the heteroscedasticity adjustment. ${ }^{*}$ represents $p<0.1,{ }^{* *}$ represents $p<0.05$ and ${ }^{* * *}$ represents $p<0.01$.

\section{Robustness Tests}

\subsection{Sensitivity Testing of CSR on Eco-Environmental Indicators}

Regarding the measure of corporate social responsibility on Eco-environment, from the existing literature, there is no unified standard. Therefore, we chose two indicators, EnvCsr ratio and YnEnv, to replace the dependent variables and re-test the model in regression. Specifically, EnvCsr_ratio is calculated as (positive environmental behavior score summed/maximum possible score)—(negative environmental behavior score summed/maximum possible score) [48]; YnEnv represents whether the firm disclosed environmental and sustainable development in that year and is 1 if yes and 0 otherwise. The regression results are shown in columns (1) and (2) of Table 4, respectively, and the coefficients of Nati are both significantly positive, indicating that the hometown identity of local executives significantly increases the level of environmental corporate social responsibility fulfillment, which indicates that our results are robust. 
Table 4. Robustness Checks on CESR Indicators.

\begin{tabular}{|c|c|c|}
\hline & (1) & (2) \\
\hline & EnvCsr_ratio & $Y n E n v$ \\
\hline Nati & $\begin{array}{c}0.037 * * * \\
(5.14)\end{array}$ & $\begin{array}{c}0.012 * * * \\
(2.64)\end{array}$ \\
\hline Size & $\begin{array}{c}0.035^{* * *} \\
(10.08)\end{array}$ & $\begin{array}{c}0.006^{* * *} \\
(2.92)\end{array}$ \\
\hline Lev & $\begin{array}{l}-0.025 \\
(-1.04)\end{array}$ & $\begin{array}{l}0.013 \\
(0.89)\end{array}$ \\
\hline Grow & $\begin{array}{c}-0.030 * * * \\
(-3.48)\end{array}$ & $\begin{array}{l}-0.001 \\
(-0.16)\end{array}$ \\
\hline Roa & $\begin{array}{c}0.337 * * * \\
(4.04)\end{array}$ & $\begin{array}{l}-0.016 \\
(-0.25)\end{array}$ \\
\hline Fcf & $\begin{array}{l}-0.044 \\
(-0.77)\end{array}$ & $\begin{array}{l}-0.002 \\
(-0.04)\end{array}$ \\
\hline Soe & $\begin{array}{l}-0.012 \\
(-1.49)\end{array}$ & $\begin{array}{l}-0.007 \\
(-1.30)\end{array}$ \\
\hline Top1 & $\begin{array}{l}-0.046 \\
(-1.41)\end{array}$ & $\begin{array}{l}0.001 \\
(0.06)\end{array}$ \\
\hline Stru & $\begin{array}{c}0.066^{* *} \\
(2.08)\end{array}$ & $\begin{array}{l}-0.012 \\
(-0.63)\end{array}$ \\
\hline PerGDP & $\begin{array}{c}-0.007^{* *} \\
(-2.44)\end{array}$ & $\begin{array}{l}-0.002 \\
(-1.35)\end{array}$ \\
\hline Law & $\begin{array}{c}0.023^{* * *} \\
(9.82)\end{array}$ & $\begin{array}{l}0.002 \\
(1.47)\end{array}$ \\
\hline PM25 & $\begin{array}{l}-0.000 \\
(-0.61)\end{array}$ & $\begin{array}{l}-0.000 \\
(-0.27)\end{array}$ \\
\hline Age & $\begin{array}{l}0.001 \\
(1.58)\end{array}$ & $\begin{array}{c}0.001 * * \\
(2.40)\end{array}$ \\
\hline Gender & $\begin{array}{l}0.010 \\
(0.75)\end{array}$ & $\begin{array}{l}-0.007 \\
(-0.71)\end{array}$ \\
\hline Degree & $\begin{array}{l}0.004 \\
(0.93)\end{array}$ & $\begin{array}{l}-0.003 \\
(-0.97)\end{array}$ \\
\hline PCSQ & $\begin{array}{l}-0.001 \\
(-0.11)\end{array}$ & $\begin{array}{c}0.028^{* * *} \\
(3.83)\end{array}$ \\
\hline Constant & $\begin{array}{c}-0.684^{* * *} \\
(-8.16)\end{array}$ & $\begin{array}{c}0.790^{* * *} \\
(13.96)\end{array}$ \\
\hline $\mathrm{N}$ & 5726 & 5261 \\
\hline $\mathrm{R}^{2}$ & 0.119 & 0.055 \\
\hline
\end{tabular}

Note that the values inside the bracket are $t$-values based on the heteroscedasticity adjustment. ${ }^{*}$ represents $p<0.1,{ }^{* *}$ represents $p<0.05$ and ${ }^{* * *}$ represents $p<0.01$.

\subsection{Sensitivity Testing of Identity Indicators for Executives' Hometown}

For the key explanatory variable, hometown identity of local executives (Nati), we refer to [31] to add the following two alternative tests. First, in this paper, we measure the hometown identity of executives of listed companies in the main test, using the province as the benchmark to indicate the place of origin and comparing it with the company's registered province. This is mainly because when we manually collected information on the hometown of the chairman and general manager of listed companies, we found that a large proportion of executives' hometown information was disclosed only at the provincial level, and only a few of them were specific to a city. It may be too crude to use administrative provinces to replace hometowns, so we used a combination of provinces or cities to match with executives' hometowns to measure executives' hometown identification. In general, if we could search for the city of the executive's hometown, we used the hometown city to compare with the city where the company was registered and assigned a value of 1 to Nati if the two matched or 0 if they did not match; for the sample of companies where the executive's hometown cannot be searched, we still used the province as the base for matching and assigned a value of 1 to Nati if the two matched or 0 if they did not 
match. After the above process, we tried to preserve the sample while incorporating the information of the city where the executives were from. Column (1) of Table 5 reports the regression results after re-assigning Nati as described above, and it can be found that the estimated coefficient of Nati is still significantly positive, which is consistent with the previous results.

Table 5. Robustness Tests on the Identity Indicators of Executives' Hometown.

\begin{tabular}{|c|c|c|}
\hline & By Place of Origin & By Place of Birth \\
\hline & (1) & (2) \\
\hline & $E n v C s r$ & $E n v C s r$ \\
\hline \multirow[t]{2}{*}{ Nati } & $0.119 * * *$ & $0.130 * *$ \\
\hline & $(2.76)$ & $(2.35)$ \\
\hline \multirow[t]{2}{*}{ Size } & $0.356^{* * *}$ & $0.404^{* * *}$ \\
\hline & $(17.64)$ & $(15.37)$ \\
\hline \multirow[t]{2}{*}{ Lev } & 0.021 & -0.259 \\
\hline & $(0.15)$ & $(-1.34)$ \\
\hline \multirow[t]{2}{*}{ Grow } & $-0.139^{* * *}$ & -0.071 \\
\hline & $(-2.62)$ & $(-1.01)$ \\
\hline \multirow[t]{2}{*}{ Roa } & $1.058^{* *}$ & 0.670 \\
\hline & $(2.25)$ & $(1.05)$ \\
\hline \multirow[t]{2}{*}{ Fcf } & 0.486 & $0.818 *$ \\
\hline & $(1.46)$ & $(1.91)$ \\
\hline \multirow[t]{2}{*}{ Soe } & 0.035 & 0.081 \\
\hline & $(0.70)$ & (1.32) \\
\hline \multirow[t]{2}{*}{ Top1 } & $-0.506^{* * *}$ & $-0.620^{* *}$ \\
\hline & $(-2.62)$ & $(-2.55)$ \\
\hline \multirow[t]{2}{*}{ Stru } & $0.559^{* * *}$ & 0.326 \\
\hline & $(3.04)$ & $(1.36)$ \\
\hline \multirow[t]{2}{*}{ PerGDP } & $-0.050 * * *$ & $-0.056^{* * *}$ \\
\hline & $(-3.20)$ & $(-2.74)$ \\
\hline \multirow[t]{2}{*}{ Law } & $0.110 * * *$ & $0.114 * * *$ \\
\hline & $(7.98)$ & $(6.43)$ \\
\hline \multirow[t]{2}{*}{ PM25 } & -0.002 & $-0.003 *$ \\
\hline & $(-1.38)$ & $(-1.69)$ \\
\hline \multirow[t]{2}{*}{ Age } & $0.015^{* * *}$ & $0.010 *$ \\
\hline & $(3.61)$ & $(1.84)$ \\
\hline \multirow[t]{2}{*}{ Gender } & -0.049 & -0.110 \\
\hline & $(-0.65)$ & $(-1.11)$ \\
\hline \multirow[t]{2}{*}{ Degree } & -0.019 & -0.031 \\
\hline & $(-0.73)$ & $(-0.93)$ \\
\hline \multirow[t]{2}{*}{ PCSQ } & 0.110 * & 0.094 \\
\hline & (1.67) & (1.11) \\
\hline \multirow[t]{2}{*}{ Constant } & $-6.926^{* * *}$ & $-7.395^{* * *}$ \\
\hline & $(-13.81)$ & $(-11.60)$ \\
\hline $\mathrm{N}$ & 5726 & 3702 \\
\hline $\mathrm{R}^{2}$ & 0.167 & 0.168 \\
\hline
\end{tabular}

Note that the values inside the bracket are $t$-values based on the heteroscedasticity adjustment. ${ }^{*}$ represents $p<0.1{ }^{* *}$ represents $p<0.05$ and ${ }^{* * *}$ represents $p<0.01$.

Second, corporate executives may identify more strongly with their birthplace. In the previous analysis, we chose to use the place of origin as a proxy for hometown identification in this paper, mainly because when we collected and organized the personal information of corporate executives, we could find the place of origin of the majority of executives, while we could only find information on the birthplace of some executives. However, in the bios of executives who disclosed both their place of origin and place of birth, we found that the two are very much the same. This means that measuring hometown identification by executive origin and birthplace should not have a significant impact on our conclusions. However, based on robustness considerations, we conducted a sensitivity test using executives' place of birth. Table 5 (2) reports the results of the regression test 
based on the executive's birthplace measure of hometown identity. It can be found that the estimated coefficient of hometown identity (Nati) of local executives remains significantly positive and is not significantly different from the regression estimation results using place of origin as the executive's hometown.

\section{Further Analysis \\ 6.1. Mechanism Testing}

If hypothesis H1a is accepted, it is implied that local executives' hometown identity promotes better CESR behavior. In a previous paper, we analyzed the role of local executives' hometown identity on their CESR performance based on identity economics; i.e., local executives may protect their hometown environment and actively perform CESR out of their love for their hometown or in response to social pressure (public opinion or reputation) brought about by their hometown identity. In this context, what are the mechanisms of local executives' active fulfillment of social responsibility on Eco-Environment and which of the two mechanisms is more important? This paper further explores this issue. If the mechanism of local executives in promoting the fulfillment of CESR is more reflected in the strong love for their hometown out of their hometown identity and they actively and voluntarily protect their hometown environment and improve the fulfillment level of CESR, then it can be expected that the external social pressure in the local executives' area, despite its magnitude, will not affect the level of fulfillment of CESR by local executives. On the contrary, if the mechanism of local executives' role in promoting CESR fulfillment is more reflected in local executives' response to the social pressure they face based on their hometown identity rather than out of their own subjective willingness to protect their hometown environment, then it can be expected that the level of CESR fulfillment is higher when local executives face greater social pressure.

In light of the previous analysis, we propose the following competing hypotheses:

Hypothesis 2 (H2a). The facilitating effect of local executives on CESR fulfillment is stronger in regions with stronger public environmental awareness compared to regions with weaker public environmental awareness.

Hypothesis $2 \mathbf{( H 2 b ) . ~ T h e r e ~ i s ~ n o ~ d i f f e r e n c e ~ i n ~ t h e ~ c o n t r i b u t i o n ~ o f ~ l o c a l ~ e x e c u t i v e s ~ t o ~ C E S R ~}$ fulfillment in regions with stronger and weaker public environmental awareness.

To test Hypothesis 2, we divide the sample into two groups based on the median annual average PM2.5 concentration in the province where the firm is located, namely those with good regional environmental quality and those with poor regional environmental quality. If there is a significant negative relationship between executives' hometown identification and both positive and negative environmental behaviors in the sample with good environmental quality, it means that the external pressure plays a larger role, i.e., executives' moral sense of the environment prevails.

Since in regions with superior environmental quality, the social public has a stronger awareness of environmental protection [31], accordingly, the social public has higher expectations of local executives to protect their hometown environment, and if local executives do not actively protect or even destroy their hometown environment, they will be strongly condemned by the local public and thus face greater social pressure, while in regions with poor environmental quality, the social public's awareness of environmental protection is relatively weak, local executives are subject to less social pressure from the public's need to protect the environment due to their hometown status. Furthermore, if executives can actively promote positive environmental behaviors while actively avoiding negative environmental behaviors, it can also indicate that executives have the will to protect the environment. Therefore, we divided the sample into two groups of high social pressure (good regional environmental quality) and low social pressure (poor regional environmental quality) based on the median annual average concentration of PM2.5 in the 
province where the company is located for regression analysis to test Hypothesis $\mathrm{H} 2$, and the regression results are shown in column (1) and (2) of Table 6.

Table 6. Mechanism Testing.

\begin{tabular}{|c|c|c|c|c|}
\hline & \multicolumn{2}{|c|}{ Regional Environmental Quality } & \multicolumn{2}{|c|}{ Industry Performance Pressure } \\
\hline & High External Pressure & Low External Pressure & High External Pressure & Low External Pressure \\
\hline & (1) & (2) & (3) & (4) \\
\hline & EnvCsr & EnvCsr & EnvCsr & EnvCsr \\
\hline Nati & $\begin{array}{c}0.180 * * * \\
(3.07)\end{array}$ & $\begin{array}{l}0.069 \\
(1.04)\end{array}$ & $\begin{array}{c}0.180 * * * \\
(3.49)\end{array}$ & $\begin{array}{l}0.023 \\
(0.28)\end{array}$ \\
\hline Size & $\begin{array}{c}0.402 * * * \\
(13.31)\end{array}$ & $\begin{array}{c}0.322^{* * *} \\
(10.72)\end{array}$ & $\begin{array}{c}0.373^{* * *} \\
(15.38)\end{array}$ & $\begin{array}{c}0.337^{* * *} \\
(8.13)\end{array}$ \\
\hline Lev & $\begin{array}{l}-0.092 \\
(-0.48)\end{array}$ & $\begin{array}{l}0.216 \\
(0.97)\end{array}$ & $\begin{array}{l}-0.021 \\
(-0.12)\end{array}$ & $\begin{array}{l}0.254 \\
(0.95)\end{array}$ \\
\hline Grow & $\begin{array}{c}-0.218^{* * * *} \\
(-2.99)\end{array}$ & $\begin{array}{l}-0.037 \\
(-0.47)\end{array}$ & $\begin{array}{l}-0.120 \text { * } \\
(-1.76)\end{array}$ & $\begin{array}{l}-0.147 \text { * } \\
(-1.87)\end{array}$ \\
\hline Roa & $\begin{array}{c}1.128 * \\
(1.78)\end{array}$ & $\begin{array}{l}1.049 \\
(1.45)\end{array}$ & $\begin{array}{c}1.200 * * \\
(2.10)\end{array}$ & $\begin{array}{l}0.411 \\
(0.49)\end{array}$ \\
\hline Fcf & $\begin{array}{l}0.322 \\
(0.70)\end{array}$ & $\begin{array}{c}0.878^{*} \\
(1.77)\end{array}$ & $\begin{array}{l}0.591 \\
(1.43)\end{array}$ & $\begin{array}{l}0.342 \\
(0.59)\end{array}$ \\
\hline Soe & $\begin{array}{c}0.161^{* *} \\
(2.31)\end{array}$ & $\begin{array}{l}-0.119 * \\
(-1.65)\end{array}$ & $\begin{array}{l}-0.101 \text { * } \\
(-1.72)\end{array}$ & $\begin{array}{c}0.338^{* * *} \\
(3.75)\end{array}$ \\
\hline Top1 & $\begin{array}{c}-0.906^{* * *} \\
(-3.32)\end{array}$ & $\begin{array}{l}-0.040 \\
(-0.14)\end{array}$ & $\begin{array}{l}-0.432 * \\
(-1.90)\end{array}$ & $\begin{array}{l}-0.760 * \\
(-1.96)\end{array}$ \\
\hline Stru & $\begin{array}{c}0.848^{* * *} \\
(3.19)\end{array}$ & $\begin{array}{l}0.296 \\
(1.13)\end{array}$ & $\begin{array}{c}0.547^{* *} \\
(2.52)\end{array}$ & $\begin{array}{c}0.826^{* *} \\
(2.28)\end{array}$ \\
\hline PerGDP & $\begin{array}{c}-0.087^{* * *} \\
(-3.39)\end{array}$ & $\begin{array}{l}-0.038 \\
(-1.36)\end{array}$ & $\begin{array}{c}-0.050 * * * \\
(-2.74)\end{array}$ & $\begin{array}{c}-0.080 * * * \\
(-2.73)\end{array}$ \\
\hline Law & $\begin{array}{c}0.134^{* * *} \\
(7.83)\end{array}$ & $\begin{array}{c}0.094^{* * *} \\
(3.22)\end{array}$ & $\begin{array}{c}0.115^{* * *} \\
(7.08)\end{array}$ & $\begin{array}{c}0.120^{* * *} \\
(4.71)\end{array}$ \\
\hline PM25 & $\begin{array}{l}0.004 \\
(0.98)\end{array}$ & $\begin{array}{c}0.011^{* * *} \\
(3.01)\end{array}$ & $\begin{array}{l}-0.002 \\
(-1.11)\end{array}$ & $\begin{array}{l}-0.003 \\
(-0.86)\end{array}$ \\
\hline Age & $\begin{array}{c}0.015^{* *} \\
(2.53)\end{array}$ & $\begin{array}{c}0.017^{* * * *} \\
(2.62)\end{array}$ & $\begin{array}{c}0.013^{* *} \\
(2.40)\end{array}$ & $\begin{array}{c}0.028^{* * *} \\
(3.54)\end{array}$ \\
\hline Gender & $\begin{array}{l}-0.164 \\
(-1.60)\end{array}$ & $\begin{array}{l}0.183 \\
(1.57)\end{array}$ & $\begin{array}{l}0.008 \\
(0.09)\end{array}$ & $\begin{array}{l}-0.082 \\
(-0.63)\end{array}$ \\
\hline Degree & $\begin{array}{c}-0.102 * * * \\
(-2.75)\end{array}$ & $\begin{array}{c}0.091 \text { ** } \\
(2.32)\end{array}$ & $\begin{array}{l}-0.027 \\
(-0.85)\end{array}$ & $\begin{array}{l}0.012 \\
(0.24)\end{array}$ \\
\hline PCSQ & $\begin{array}{l}0.048 \\
(0.52)\end{array}$ & $\begin{array}{c}0.176^{*} \\
(1.85)\end{array}$ & $\begin{array}{l}0.095 \\
(1.25)\end{array}$ & $\begin{array}{l}0.204 \\
(1.53)\end{array}$ \\
\hline Constant & $\begin{array}{c}-7.197^{* * *} \\
(-10.56)\end{array}$ & $\begin{array}{c}-8.387^{* * *} \\
(-9.85)\end{array}$ & $\begin{array}{c}-6.566^{* * *} \\
(-9.18)\end{array}$ & $\begin{array}{c}-8.276^{* * *} \\
(-8.90)\end{array}$ \\
\hline $\mathrm{N}$ & 3021 & 2606 & 4127 & 1500 \\
\hline$R^{2}$ & 0.193 & 0.176 & 0.159 & 0.191 \\
\hline
\end{tabular}

Note that the values inside the bracket are $t$-values based on the heteroscedasticity adjustment. * represents $p<0.1,{ }^{* *}$ represents $p<0.05$ and ${ }^{* * *}$ represents $p<0.01$.

In addition, the performance of environmental CSR by other companies in the same industry is also a social pressure that cannot be ignored. When other companies in the industry are actively performing environmental CSR, the company's evasion of environmental CSR will be pressured by peers. It is also easy to be noticed by the society in the hometown. Therefore, we group according to the performance of environmental CSR in the same industry. If the environmental CSR level of the industry in which the company is located is greater than or equal to the CSR level of all listed companies, it indicates that the company will bear greater social pressure from the industry; on the contrary, the company faces less social pressure. On this basis, we grouped the samples, and the results are shown in column (3) and (4) of Table 6. 
From the results in Table 6, it can be seen that under the two grouping methods, the regression results indicate that the role of promoting the fulfillment of corporate environmental social responsibility is significant only when local executives face greater social pressure, while when local executives face less social pressure, their role on the fulfillment of corporate environmental social responsibility is not significantly different from that of non-local executives. Therefore, Hypothesis $\mathrm{H} 2 \mathrm{a}$ is confirmed; i.e., the contribution of local executives to CESR fulfillment is stronger when they face greater social pressure based on their hometown status.

\subsection{Regional Heterogeneity: Regional Economic Development Level, Regional Legal Environment Level}

In the above section, we argued that when the company is registered in the hometown of the executives, companies with executives in their hometowns are more inclined to perform environmental CSR. The mechanism test shows that this effect is mainly due to the greater external pressure faced by executives in their hometowns. In the above test, the hometown of senior executives is heterogeneous, and there are differences in the level of regional economic development and legal environment, which will also affect the relationship between the preference of senior executives' hometown and environmental CSR. Therefore, we separately carried out the heterogeneity test of the regional economic development level and the regional legal environment level.

Hometown favoritism is part of the informal system. Its essence depends on traditional culture and ideas. Economic development and the legal environment belong to the scope of the formal system. When the formal system is relatively complete, the role of the informal system will be limited. First of all, if the level of regional economic development and the level of legal environment are higher, local executives will perform at a higher level of environmental CSR under the constraints of the formal system, and the informal system of hometown favoritism will become insignificant in terms of environmental CSR. Only when the level of economic development is low and the level of legal environment is poor, the absence of formal institutions will make hometown favoritism play a greater role, and social pressure and other informal institutions based on local mass consciousness will become prominent. Therefore, we speculate that the effect of hometown's favoritism to promote the development of environmental CSR mainly exists in areas with a low level of economic development and a relatively backward level of regional legal environment.

Based on the median of regional GDP per capita and the median of the legal level in the degree of marketization, we divided the sample into two groups. The results are shown in columns (1)-(4) of Table 7. The result of hometown's favoritism to promote CSR development mainly exists in areas with low economic levels and poor local legal environment, which is consistent with our speculation.

\subsection{Executive Characteristics: Influence of Executive Type and Age}

On one hand, although both the chairman and the CEO are corporate executives who play an important role in corporate decision making, the specific responsibilities of the two are different. Although the chairman can play an advisory function on the board of directors by making suggestions and influencing decisions to protect the environment in his hometown, it is the CEO who is specifically responsible for decision implementation. Therefore, we further examine whether there are differences in the roles of different types of executives, i.e., the local chairman (Nati_Chair) and the local CEO (Nati_CEO), in promoting the fulfillment of corporate social responsibility on Eco-environment. The regression results of the sub-group test are shown in columns (1) and (2) of Table 8, where the regression coefficients of both Nati_Chair and Nati_CEO are positive with a significance level of $1 \%$, indicating that both the chairman and the CEO can positively promote the fulfillment of CESR when their hometown is in line with the location of the company they work for. 
Table 7. Influence of Regional Heterogeneity.

\begin{tabular}{|c|c|c|c|c|}
\hline & $\begin{array}{c}\text { Good Economic } \\
\text { Development }\end{array}$ & $\begin{array}{l}\text { Bad Economic } \\
\text { Development }\end{array}$ & $\begin{array}{l}\text { Good Legal } \\
\text { Environment }\end{array}$ & $\begin{array}{c}\text { Bad Legal } \\
\text { Environment }\end{array}$ \\
\hline & (1) & (2) & (3) & (4) \\
\hline & EnvCsr & EnvCsr & EnvCsr & EnvCsr \\
\hline Nati & $\begin{array}{l}0.008 \\
(0.11)\end{array}$ & $\begin{array}{c}0.236 * * * \\
(4.07)\end{array}$ & $\begin{array}{l}-0.020 \\
(-0.28)\end{array}$ & $\begin{array}{c}0.275 * * * \\
(4.76)\end{array}$ \\
\hline Size & $\begin{array}{c}0.400^{* * *} \\
(13.77)\end{array}$ & $\begin{array}{c}0.326^{* * *} \\
(10.68)\end{array}$ & $\begin{array}{c}0.400^{* * *} \\
(13.57)\end{array}$ & $\begin{array}{l}0.312^{* * *} \\
(10.21)\end{array}$ \\
\hline Lev & $\begin{array}{l}0.167 \\
(0.77)\end{array}$ & $\begin{array}{l}0.025 \\
(0.13)\end{array}$ & $\begin{array}{l}0.096 \\
(0.45)\end{array}$ & $\begin{array}{l}0.171 \\
(0.85)\end{array}$ \\
\hline Grow & $\begin{array}{c}-0.225^{* * *} \\
(-2.85)\end{array}$ & $\begin{array}{l}-0.067 \\
(-0.88)\end{array}$ & $\begin{array}{c}-0.151^{* *} \\
(-2.01)\end{array}$ & $\begin{array}{l}-0.126 \\
(-1.62)\end{array}$ \\
\hline Roa & $\begin{array}{l}0.470 \\
(0.73)\end{array}$ & $\begin{array}{c}1.773^{* *} \\
(2.52)\end{array}$ & $\begin{array}{l}0.675 \\
(1.00)\end{array}$ & $\begin{array}{c}1.601 \text { ** } \\
(2.40)\end{array}$ \\
\hline Fcf & $\begin{array}{l}0.735 \\
(1.42)\end{array}$ & $\begin{array}{l}0.347 \\
(0.78)\end{array}$ & $\begin{array}{l}0.464 \\
(0.91)\end{array}$ & $\begin{array}{l}0.349 \\
(0.78)\end{array}$ \\
\hline Soe & $\begin{array}{l}0.108 \\
(1.48)\end{array}$ & $\begin{array}{l}-0.072 \\
(-1.04)\end{array}$ & $\begin{array}{c}0.137^{*} \\
(1.85)\end{array}$ & $\begin{array}{l}-0.134 \\
(-1.94)\end{array}$ \\
\hline Top1 & $\begin{array}{c}-0.734^{* *} \\
(-2.57)\end{array}$ & $\begin{array}{l}-0.111 \\
(-0.41)\end{array}$ & $\begin{array}{c}-0.606^{* *} \\
(-2.09)\end{array}$ & $\begin{array}{l}-0.242 \\
(-0.91)\end{array}$ \\
\hline Stru & $\begin{array}{c}0.676^{* *} \\
(2.39)\end{array}$ & $\begin{array}{l}0.214 \\
(0.86)\end{array}$ & $\begin{array}{c}0.610^{* *} \\
(2.16)\end{array}$ & $\begin{array}{l}0.315 \\
(1.27)\end{array}$ \\
\hline PerGDP & $\begin{array}{c}-0.112^{* * * *} \\
(-4.44)\end{array}$ & $\begin{array}{l}0.045 \\
(1.30)\end{array}$ & $\begin{array}{c}-0.110^{* * *} \\
(-3.76)\end{array}$ & $\begin{array}{l}0.019 \\
(0.69)\end{array}$ \\
\hline Law & $\begin{array}{c}0.156^{* * *} \\
(8.23)\end{array}$ & $\begin{array}{c}0.069 * * * \\
(2.88)\end{array}$ & $\begin{array}{c}0.151^{* * *} \\
(6.87)\end{array}$ & $\begin{array}{c}0.058^{* * *} \\
(2.60)\end{array}$ \\
\hline PM25 & $\begin{array}{c}0.004 \\
(1.56)\end{array}$ & $\begin{array}{c}-0.005^{* *} \\
(-2.17)\end{array}$ & $\begin{array}{l}-0.001 \\
(-0.32)\end{array}$ & $\begin{array}{l}-0.002 \\
(-0.79)\end{array}$ \\
\hline Age & $\begin{array}{c}0.016^{* *} \\
(2.54)\end{array}$ & $\begin{array}{c}0.017^{* * *} \\
(2.64)\end{array}$ & $\begin{array}{c}0.016^{* * *} \\
(2.60)\end{array}$ & $\begin{array}{c}0.018^{* * *} \\
(2.86)\end{array}$ \\
\hline Gender & $\begin{array}{l}-0.137 \\
(-1.17)\end{array}$ & $\begin{array}{l}0.001 \\
(0.01)\end{array}$ & $\begin{array}{l}-0.143 \\
(-1.24)\end{array}$ & $\begin{array}{l}0.029 \\
(0.29)\end{array}$ \\
\hline Degree & $\begin{array}{l}-0.050 \\
(-1.29)\end{array}$ & $\begin{array}{l}0.017 \\
(0.46)\end{array}$ & $\begin{array}{c}-0.075^{* *} \\
(-1.96)\end{array}$ & $\begin{array}{l}0.024 \\
(0.62)\end{array}$ \\
\hline PCSQ & $\begin{array}{c}0.258^{* * *} \\
(2.67)\end{array}$ & $\begin{array}{l}0.040 \\
(0.44)\end{array}$ & $\begin{array}{c}0.259^{* * *} \\
(2.61)\end{array}$ & $\begin{array}{l}0.031 \\
(0.34)\end{array}$ \\
\hline Constant & $\begin{array}{c}-8.341^{* * *} \\
(-11.80)\end{array}$ & $\begin{array}{c}-6.537 * * * \\
(-9.56)\end{array}$ & $\begin{array}{c}-8.077^{* * *} \\
(-9.74)\end{array}$ & $\begin{array}{c}-6.299 * * * \\
(-9.04)\end{array}$ \\
\hline $\mathrm{N}$ & 2821 & 2806 & 2828 & 2799 \\
\hline$R^{2}$ & 0.215 & 0.125 & 0.204 & 0.136 \\
\hline
\end{tabular}

Note that the values inside the bracket are $t$-values based on the heteroscedasticity adjustment. ${ }^{*}$ represents $p<0.1,{ }^{* *}$ represents $p<0.05$ and **** represents $p<0.01$

On the other hand, the higher-order theory proposed by [49] suggests that corporate executives make highly personalized interpretations of the situations and choices they face and act on them. In this paper, we find that the hometown identity of local executives can significantly contribute to the fulfillment of CESR, which to some extent explains the influence of executives' ultimate perceptions and values on decision making. In addition to this, based on the Upper Echelons Theory, we also examine the effect of age, an observable factor influencing executives' decision making. Columns (3) and (4) of Table 8 report the regression results after grouping executives according to the annual industry median of their age. The results show that when local executives are older, local executives actively promote CESR based on their hometown identity, but when local executives are younger, this promotion effect is no longer significant. 
Table 8. Influence of Executive Characteristics and Nature of Property Right.

\begin{tabular}{|c|c|c|c|c|c|c|}
\hline & \multicolumn{2}{|c|}{ Executive Type } & \multicolumn{2}{|c|}{ Age } & \multicolumn{2}{|c|}{ Nature of Property Right } \\
\hline & (1) & (2) & (3) & (4) & (5) & (6) \\
\hline & Chairman & CEO & Young & Old & Private & SOE \\
\hline & EnvCsr & EnvCsr & EnvCsr & EnvCsr & EnvCsr & EnvCsr \\
\hline Nati_Chair & $\begin{array}{c}0.162 * * * \\
(3.60)\end{array}$ & & & & & \\
\hline Nati_CEO & & $\begin{array}{c}0.161 * * * \\
(3.02)\end{array}$ & & & & \\
\hline Nati & & & $\begin{array}{l}0.071 \\
(1.20)\end{array}$ & $\begin{array}{c}0.224 * * * \\
(3.46)\end{array}$ & $\begin{array}{l}-0.062 \\
(-0.89)\end{array}$ & $\begin{array}{c}0.261 * * * \\
(4.52)\end{array}$ \\
\hline Size & $\begin{array}{c}0.363^{* * *} \\
(17.46)\end{array}$ & $\begin{array}{c}0.365^{* * *} \\
(17.58)\end{array}$ & $\begin{array}{c}0.386^{* * *} \\
(12.96)\end{array}$ & $\begin{array}{c}0.355^{* * *} \\
(11.96)\end{array}$ & $\begin{array}{c}0.361^{* * *} \\
(8.56)\end{array}$ & $\begin{array}{c}0.371^{* * *} \\
(15.00)\end{array}$ \\
\hline Lev & $\begin{array}{l}0.046 \\
(0.32)\end{array}$ & $\begin{array}{l}0.060 \\
(0.42)\end{array}$ & $\begin{array}{l}-0.041 \\
(-0.21)\end{array}$ & $\begin{array}{l}0.070 \\
(0.32)\end{array}$ & $\begin{array}{l}0.199 \\
(0.78)\end{array}$ & $\begin{array}{l}0.168 \\
(0.94)\end{array}$ \\
\hline Grow & $\begin{array}{c}-0.130^{* *} \\
(-2.41)\end{array}$ & $\begin{array}{c}-0.132 \text { ** } \\
(-2.46)\end{array}$ & $\begin{array}{c}-0.155^{* *} \\
(-2.19)\end{array}$ & $\begin{array}{l}-0.093 \\
(-1.10)\end{array}$ & $\begin{array}{l}-0.076 \\
(-1.04)\end{array}$ & $\begin{array}{l}-0.148 \text { * } \\
(-1.88)\end{array}$ \\
\hline Roa & $\begin{array}{c}1.156^{* *} \\
(2.44)\end{array}$ & $\begin{array}{c}1.181^{* *} \\
(2.50)\end{array}$ & $\begin{array}{c}1.771^{* * *} \\
(2.96)\end{array}$ & $\begin{array}{l}0.181 \\
(0.23)\end{array}$ & $\begin{array}{c}1.139 * \\
(1.69)\end{array}$ & $\begin{array}{c}1.186 * \\
(1.76)\end{array}$ \\
\hline Fcf & $\begin{array}{l}0.462 \\
(1.37)\end{array}$ & $\begin{array}{l}0.456 \\
(1.36)\end{array}$ & $\begin{array}{c}0.756 \text { * } \\
(1.68)\end{array}$ & $\begin{array}{l}0.130 \\
(0.25)\end{array}$ & $\begin{array}{l}-0.528 \\
(-1.08)\end{array}$ & $\begin{array}{c}1.172 * * \\
(2.53)\end{array}$ \\
\hline Soe & $\begin{array}{l}0.026 \\
(0.52)\end{array}$ & $\begin{array}{l}0.014 \\
(0.28)\end{array}$ & $\begin{array}{l}0.059 \\
(0.87)\end{array}$ & $\begin{array}{l}-0.012 \\
(-0.16)\end{array}$ & $\begin{array}{l}- \\
-\end{array}$ & $\begin{array}{l}- \\
-\end{array}$ \\
\hline Top1 & $\begin{array}{c}-0.498^{* *} \\
(-2.55)\end{array}$ & $\begin{array}{c}-0.503^{* *} \\
(-2.57)\end{array}$ & $\begin{array}{c}-0.518^{*} \\
(-1.88)\end{array}$ & $\begin{array}{l}-0.512 * \\
(-1.80)\end{array}$ & $\begin{array}{c}-1.030 * * * \\
(-3.11)\end{array}$ & $\begin{array}{l}-0.289 \\
(-1.17)\end{array}$ \\
\hline Stru & $\begin{array}{c}0.570 * * * \\
(3.06)\end{array}$ & $\begin{array}{c}0.555^{* * *} \\
(2.98)\end{array}$ & $\begin{array}{c}0.754^{* * *} \\
(2.98)\end{array}$ & $\begin{array}{c}0.521 * \\
(1.85)\end{array}$ & $\begin{array}{c}1.099^{* * *} \\
(3.51)\end{array}$ & $\begin{array}{l}0.304 \\
(1.23)\end{array}$ \\
\hline PerGDP & $\begin{array}{c}-0.052 \text { *** } \\
(-3.36)\end{array}$ & $\begin{array}{c}-0.056^{* * *} \\
(-3.62)\end{array}$ & $\begin{array}{c}-0.045^{* *} \\
(-2.12)\end{array}$ & $\begin{array}{c}-0.058^{* *} \\
(-2.50)\end{array}$ & $\begin{array}{c}-0.054^{* *} \\
(-2.15)\end{array}$ & $\begin{array}{c}-0.052 * * * \\
(-2.58)\end{array}$ \\
\hline Law & $\begin{array}{c}0.114^{* * *} \\
(8.30)\end{array}$ & $\begin{array}{c}0.114^{* * *} \\
(8.34)\end{array}$ & $\begin{array}{c}0.108^{* * * *} \\
(5.74)\end{array}$ & $\begin{array}{c}0.118^{* * *} \\
(5.76)\end{array}$ & $\begin{array}{c}0.086^{* * *} \\
(4.00)\end{array}$ & $\begin{array}{c}0.132 * * * \\
(7.40)\end{array}$ \\
\hline PM25 & $\begin{array}{l}-0.002 \\
(-1.62)\end{array}$ & $\begin{array}{l}-0.002 \\
(-1.55)\end{array}$ & $\begin{array}{l}-0.003 \\
(-1.39)\end{array}$ & $\begin{array}{l}-0.002 \\
(-0.76)\end{array}$ & $\begin{array}{l}-0.001 \\
(-0.37)\end{array}$ & $\begin{array}{l}-0.004 \text { * } \\
(-1.87)\end{array}$ \\
\hline Age & $\begin{array}{c}0.017^{* * *} \\
(3.77)\end{array}$ & $\begin{array}{c}0.017^{* * *} \\
(3.85)\end{array}$ & $\begin{array}{c}0.018 \text { * } \\
(1.94)\end{array}$ & $\begin{array}{c}0.023 \text { ** } \\
(2.21)\end{array}$ & $\begin{array}{c}0.025^{* * *} \\
(4.35)\end{array}$ & $\begin{array}{l}0.006 \\
(0.84)\end{array}$ \\
\hline Gender & $\begin{array}{l}-0.038 \\
(-0.50)\end{array}$ & $\begin{array}{l}-0.039 \\
(-0.50)\end{array}$ & $\begin{array}{l}-0.056 \\
(-0.55)\end{array}$ & $\begin{array}{l}0.000 \\
(0.00)\end{array}$ & $\begin{array}{c}-0.216^{* *} \\
(-2.31)\end{array}$ & $\begin{array}{l}0.081 \\
(0.63)\end{array}$ \\
\hline Degree & $\begin{array}{l}-0.021 \\
(-0.78)\end{array}$ & $\begin{array}{l}-0.019 \\
(-0.73)\end{array}$ & $\begin{array}{l}-0.026 \\
(-0.65)\end{array}$ & $\begin{array}{l}-0.018 \\
(-0.49)\end{array}$ & $\begin{array}{l}-0.011 \\
(-0.27)\end{array}$ & $\begin{array}{l}-0.028 \\
(-0.77)\end{array}$ \\
\hline PCSQ & $\begin{array}{c}0.109 * \\
(1.66)\end{array}$ & $\begin{array}{c}0.113 * \\
(1.73)\end{array}$ & $\begin{array}{l}-0.001 \\
(-0.01)\end{array}$ & $\begin{array}{c}0.198 * * \\
(2.05)\end{array}$ & $\begin{array}{c}0.226^{* *} \\
(1.97)\end{array}$ & $\begin{array}{l}0.063 \\
(0.76)\end{array}$ \\
\hline Constant & $\begin{array}{c}-7.206^{* * *} \\
(-13.90)\end{array}$ & $\begin{array}{c}-7.225^{* * *} \\
(-13.97)\end{array}$ & $\begin{array}{c}-7.870 * * * \\
(-10.42)\end{array}$ & $\begin{array}{c}-7.170^{* * *} \\
(-7.23)\end{array}$ & $\begin{array}{c}-7.925^{* * *} \\
(-8.29)\end{array}$ & $\begin{array}{c}-6.340^{* * *} \\
(-9.26)\end{array}$ \\
\hline $\mathrm{N}$ & 5630 & 5630 & 3006 & 2624 & 2191 & 3439 \\
\hline $\mathrm{R}^{2}$ & 0.172 & 0.171 & 0.162 & 0.173 & 0.171 & 0.181 \\
\hline
\end{tabular}

Note that the values inside the bracket are $t$-values based on the heteroscedasticity adjustment. ${ }^{*}$ represents $p<0.1,{ }^{* *}$ represents $p<0.05$ and ${ }^{* * *}$ represents $p<0.01$.

\subsection{Impact of the Nature of Property Rights}

The fulfillment of corporate social responsibility on Eco-environment requires enterprises to invest capital on the one hand and to avoid production operations that pollute the environment on the other, which inevitably has an impact on the short-term economic goals of enterprises. As we all know, compared with private enterprises' profitability goal of maximizing economic benefits, state-owned enterprises have more complex business goals. In addition to obtaining economic benefits, they also bear the burden of implementing national policies, regulating the national economy and improving social welfare, which is transferred to them by the government. Specifically, SOEs are more likely to enjoy financing facilities and government subsidies [50], which can provide sufficient funds for 
their environmental investments. At the same time, SOEs have closer relationships with government agencies, and SOE executives are more likely to be subject to government intervention, more willing to invest in accordance with government-set goals [51] and more likely to take on government-assigned environmental responsibilities. The ultimate goal of executives in private enterprises is to maximize corporate value [51]. Therefore, private enterprises are constrained by profit-seeking goals and find it difficult to invest money in CESR at all costs.

On this basis, this paper divides the sample into a state-owned enterprise group and a private enterprise group according to the nature of enterprise ownership and examines the influence of local executives on corporate social responsibility on Eco-environment, respectively. Columns (5) and (6) of Table 8 show the relevant results. It can be seen that the coefficient of Nati is positively significant within the group of state-owned enterprises, while it is not significant within the group of private enterprises, which indicates that in state-owned enterprises, local executives have a significant contribution to the fulfillment of corporate social responsibility on Eco-environment, while in private enterprises, there is no such significant contribution.

\section{Conclusions}

Under the concept of sustainable development in China, the severe situation of ecological pollution in China has led the government and society to invest more resources to promote the construction of ecological environment, and as the main body of ecological environmental construction, the fulfillment of CSR on Eco-environment by enterprises has received more attention. Among the factors that affect the fulfillment of such CESR by enterprises, in addition to formal institutions such as regulations and policies, informal institutions also play a non-negligible role. We chose the perspective of executive hometown identification and studied its influence on the fulfillment of corporate social responsibility on Eco-environment. Using a sample of Chinese A-share listed companies from 2007 to 2018, this paper finds that CESR scores are higher when executives work in their hometowns, suggesting that executives' hometown identification significantly enhances the fulfillment of CESR; after conducting mechanism tests, we found that this result exists only in regions with good environmental quality, suggesting that executives take CESR more seriously in their hometowns mainly due to social pressure. In particular, public environmental awareness is stronger when the corporate environment is good, and corporate laziness in environmental protection may be more likely to stimulate social resentment; i.e., companies face more pressure and are therefore more motivated to fulfill their CESR. After group testing, we found that both executive type and age have a moderating effect on the above relationship: both the chairman and CEO have hometown identity performance, and the older the executive is, the stronger his awareness of fulfilling environmental social responsibility in his hometown. In addition, the nature of property rights of listed companies also affects executives' hometown identity. The executives of state-owned enterprises have a stronger sense of hometown identification and hence a higher degree of fulfillment of corporate environmental social responsibility.

Based on identity theory, this paper analyzes the factors influencing the fulfillment of corporate environmental social responsibility from the perspective of informal institutions, which not only complements the theories related to identity but also expands the research on the fulfillment of corporate environmental social responsibility. At the same time, this paper distinguishes mechanisms through a series of group tests, which is more conducive to our understanding of the motivation of enterprises to fulfill their CESR and helps to provide some reference and basis for government policies in encouraging enterprises to carry out environmental governance. However, limited by the availability of data, this article still has some shortcomings. In particular, it lacks a more in-depth discussion of the hometown identity of senior executives at the municipal level. It is more convincing to gather the hometown of senior executives at the municipal level than at the provincial level because of individual growth. The scope at the municipal level contains more personal emotions 
and a denser and wider social network than that at the provincial level. The characteristics of its identity then become stronger and more precise, and it is more susceptible to the influence of social pressure in the environment. The research on reducing the scope of hometown will also provide us with more research value and directions.

Author Contributions: Conceptualization, All Authors; methodology, X.R.; analysis and validation, B.S.; formal analysis, T.Z.; writing, K.L. All authors have read and agreed to the published version of the manuscript.

Funding: This work was partially supported by the National Science Foundation for Young Scientists of China [grant No. 71902163], the Humanities and Social Sciences Youth Foundation of Ministry of Education of China [grant No. 2019040027] and the Atlantic Association for Research in the Mathematical Sciences [grant No. M605059].

Institutional Review Board Statement: Not applicable.

Informed Consent Statement: Not applicable.

Data Availability Statement: The data that support the findings of this study are openly available in the Wind Financial Database at (http:/ / www.wind.com.cn) accessed on 8 January 2020, CSMAR Database at (http:/ / www.gtadata.com) and CNRDS Database at (http:/ / www.cnrds.com) accessed on 8 January 2020.

Acknowledgments: We would like to thank Polly Wang, Assistant Editor, and the editorial office for their invitations and helpful comments.

Conflicts of Interest: The authors declare no conflict of interest.

\section{References}

1. $<<$ Guideline Opinions on Building a Modern Environmental Governance Sys-tem >> Issued by the General Office of the Central Committee of the Communist Party of China and the General Office of the State Council. Available online: http: //www.gov.cn/zhengce/2020-03/03/content_5486380.htm (accessed on 1 December 2020). (In Chinese)

2. CSR Report: The Number of Social Responsibility Reports Issued by Chinese Companies Is Increasing Year by Year. Available online: http:/ / finance.sina.com.cn/esg/investment/2020-11-12/doc-iiznctke1113520.shtml (accessed on 1 December 2020). (In Chinese)

3. Ministry of Environmental Protection: The Severe Situation of Environmental Pollution and Ecological Environment Protection Has Not Fundamentally Changed. Available online: http:/ / finance.eastmoney.com/a/202010211671114353.html (accessed on 1 December 2020). (In Chinese).

4. Blacconiere, W.G.; Patten, D.M. Environmental disclosures, regulatory costs, and changes in firm value. J. Account. Econ. 1994, 18, 357-377. [CrossRef]

5. Greenstone, M.; Hanna, R. Environmental regulations, air and water pollution, and infant mortality in India. Am. Econ. Rev. 2014, 104, 3038-3072. [CrossRef]

6. Liang, P.; Gao, N. Personnel change, legal environment and local environmental pollution. Manag. World 2014, 6, 65-78. (In Chinese)

7. Aerts, W.; Cormier, D. Media legitimacy and corporate environmental communication. Account. Organ. Soc. 2009, 34, 1-27. [CrossRef]

8. Bi, Q.; Peng, J.; Zuo, Y. Environment information disclosure system, corporate governance and environment information disclosure. Account. Res. 2012, 7, 39-47. (In Chinese)

9. Weber, A.; Mao, X. On the new and old social compact theory. Foreign Theor. Trends 2012, 8, 37-50.

10. Black, F. International capital market equilibrium with investment barriers. J. Financ. Econ. 1974, 1, 337-352. [CrossRef]

11. Stulz, R.M. On the effects of barriers to international investment. J. Financ. 1981, 36, 923-934. [CrossRef]

12. Akerlof, G.A.; Kranton, R.E. Economics and identity. Q. J. Econ. 2000, 115, 715-753. [CrossRef]

13. Akerlof, G.A.; Kranton, R.E. Identity and schooling: Some lessons for the economics of education. J. Econ. Lit. 2002, 40, 1167-1201. [CrossRef]

14. Akerlof, G.A.; Kranton, R. Identity economics. Econ. Voice. 2010, 7, 1-3.

15. Coval, J.D.; Moskowitz, T.J. Home bias at home: Local equity preference in domestic portfolios. J. Financ. 1999, 54, 2045-2073. [CrossRef]

16. Hofstede, G. What is Culture? A Reply to Baskerville. Account. Organ. Soc. 2003, 28, 811-813. [CrossRef]

17. Yang, B. Identifying Valid and Reliable Measures for Dimensions of a Learning Culture. Adv. Dev. Hum. Resour. 2003, 5, 152-162. [CrossRef]

18. Hodler, R.; Raschky, P.A. Regional favoritism. Q. J. Econ. 2014, 129, 995-1033. [CrossRef] 
19. Cohen, L.; Coval, J.; Malloy, C. Do powerful politicians cause corporate downsizing? J. Political Econ. 2011, 119, 1015-1060. [CrossRef]

20. Knight, B. Legislative representation, bargaining power and the distribution of federal funds: Evidence from the U.S. congress. Econ. J. 2008, 118, 1785-1803. [CrossRef]

21. Cao, C.; Zhang, T.; Fan, Z. Market integration under regional favoritism. Econ. Res. J. 2017, 12, 91-104. (In Chinese)

22. Fan, Z.; Li, X. Political connection of ministers and the allocation of fiscal transfer. Econ. Res. J. 2014, 6, 129-141. (In Chinese)

23. Fan, Z.; Peng, F.; Liu, C. Political connections and economic growth: Evidence from the DMSP/OLS satellite data. Econ. Res. J. 2016, 1, 114-126. (In Chinese)

24. Li, S.; Xu, X. Identity and growth. China Econ. Q. 2016, 3, 941-962.

25. Qian, X.; Cao, T. Money following politicians: Local officials and interregional cash flows. Econ. Res. J. 2017, 2, 156-170. (In Chinese)

26. Zhang, P.; Zhao, G.; Luo, Z. Sources of central officials and local economic growth. China Econ. Q. 2012, 2, 613-634. (In Chinese)

27. Christensen, D.M. Corporate Accountability Reporting and High-Profile Misconduct. Account. Rev. 2016, 91, 377-399. [CrossRef]

28. Husted, B.W.; Allen, D.B. Corporate social responsibility in the multinational enterprise: Strategic and institutional approaches. J. Int. Bus. Stud. 2006, 37, 838-849. [CrossRef]

29. Aguinis, H.; Glavas, A. What we know and don't know about corporate social responsibility: A review and research agenda. J. Manag. 2012, 38, 932-968. [CrossRef]

30. Liang, S. Essentials of Chinese Culture; Zhengzhong Shuju: Taipei, China, 1949.

31. Hu, J.; Song, X.; Wang, H. Informal institution, hometown identity and corporate environmental governance. Manag. World. 2017, 3, 76-94. (In Chinese)

32. Bardhan, P.; Mookherjee, D. Decentralizing anti-poverty program delivery in developing countries. J. Public Econ. 2005, 89, 675-704. [CrossRef]

33. Bardhan, P.; Mookherjee, D. Corruption and decentralization of infrastructure delivery in developing countries. Econ. J. 2006, 116, 107-133. [CrossRef]

34. Nie, H.; Jiang, M. Coal mine accidents and collusion between local governments and firms: Evidence from provincial level panel data in China. Econ. Res. J. 2011, 6, 146-156. (In Chinese)

35. Nie, H.; Li, J. Collusions between governments and firms and economic development. China Econ. Q. 2006, 6, 75-90. (In Chinese)

36. Nie, H.; Li, Q. A new economic interpretation of the high housing price in China-From the perspective of "collusion between local governments and enterprises". Teach. Res. 2013, 1, 50-62. (In Chinese)

37. Ratter, B.M.W.; Gee, K. Heimat-A German concept of regional perception and identity as a basis for coastal management in the Warden Sea. Ocean Coast. Manag. 2012, 14, 47-59.

38. Zhai, X. The essence of trust and its culture. Chin. J. Sociol. 2014, 34, 1-26. (In Chinese)

39. Pan, Y.; Dai, Y.; Wu, C.; Liu, J. Social capital, political connections and corporate investment decision. Econ. Res. J. 2009, 44, 82-94. (In Chinese)

40. Gray, W.B.; Shadbegian, R.J. Environmental Regulation, Investment Timing, and Technology Choice. J. Ind. Econ. 1998, 46, 235-256. [CrossRef]

41. Yuan, Y.; Geng, D. Development on Environment Protect Industry of China-Based on Research of Government and Pollutant Corporation and Environment Protect Corporation. China Ind. Econ. 2010, 10, 65-74. (In Chinese)

42. Coval, J.D.; Moskowitz, T.J. The Geography of Investment: Informed Trading and Asset Prices. J. Political Econ. 2001, $109,811-841$. [CrossRef]

43. Pool, V.K.; Stoffman, N.; Yonker, S.E. No Place like Home: Familiarity in Mutual Fund Manager Portfolio Choice. Rev. Financ. Stud. 2012, 25, 2563-2599. [CrossRef]

44. Attig, N.; Boubakri, N.; El Ghoul, S.; Guedhami, O. Firm internationalization and corporate social responsibility. J. Bus. Ethics. 2016, 134, 171-197. [CrossRef]

45. Yuan, J.; Hou, Q.; Cheng, C. Curse effect of enterprise political resources-Based on the study of political connection and enterprise technological innovation. Manag. World 2015, 1, 139-155. (In Chinese)

46. Bao, Q.; Shao, M.; Yang, D. Environmental regulation, provincial legislation and pollution emission in China. Econ. Res. J. 2013, 12, 42-54. (In Chinese)

47. Long, W.; Li, S.; Song, X. Environmental regulation and the environmental performance of small and medium-sized enterprises (SMEs): Evidence from the SME board and growth enterprise board listed firms in China. J. Public Adm. 2015, 8, 25-58. (In Chinese)

48. Servaes, H.; Tamayo, A. The impact of corporate social responsibility on firm value: The role of customer awareness. Manag. Sci. 2013, 59, 1045-1061. [CrossRef]

49. Hambrick, D.C.; Mason, P.A. Upper echelons: The organization as a reflection of its top managers. Acad. Manag. Rev. 1984, 9, 193-206. [CrossRef]

50. Brandt, L.; Li, H. Bank discrimination in transition economies: Ideology, information, or incentives? J. Comp. Econ. 2003, 31, 387-413. [CrossRef]

51. Chen, S.; Sun, Z.; Tang, S.; Wu, D. Government intervention and investment efficiency: Evidence from China. J. Corp. Financ. 2011, 17, 259-271. [CrossRef] 